\title{
The Birmingham Civil Rights Institute: A Case Study in Library, Archives, and Museum Collaboration
}

TO SET THE STAGE for my comments about the mission and development of the Birmingham Civil Rights Institute (BCRI) and its successful collaborative projects with libraries, archives, and other cultural and educational institutions, I would like to begin with a bit of personal background.

As a child growing up in New Orleans, I had to sit behind a screen that separated blacks from whites when I rode on a bus, and drink from water fountains designated "colored." Libraries in New Orleans, however, were desegregated in 1955. My earliest experiences with them occurred when I was in public school, and I remember bookmobiles visiting schools in the African American community in the early 1960s. The New Orleans Museum of Art also was desegregated in the 1950s, and I first recall visiting a museum some years later while I was a student at Southern University in New Orleans. But in Birmingham, Alabama, the climate was very different. Local segregation laws were not repealed until July 1963. In retaliation, Klansmen bombed the Sixteenth Street Baptist Church, killing four little girls. As one might imagine, libraries and museums in that state were not very inviting or user-friendly places for African Americans during the turbulent years of the Civil Rights Movement.

This history of segregation and desegregation still affects library and museum visitors today. To some extent, our challenge continues to include finding meaningful ways to appeal to those who feel underrepresented, disenfranchised, and excluded from our venues. It is important that we explore creative methods for using technology and collaborate with other institutions in efforts to engage our communities. I truly believe that we all want to provide greater access to our collections to educate better the people we serve: it is an ethic embedded in our mission. To some degree or another, the missions of libraries, archives, and museums all involve the fostering of educational experiences through access to information. The particular mission of the Birmingham Civil Rights Institute is to promote civil and 
human rights worldwide through education. Our vision is to become the premiere educational center for understanding, healing, and learning to have respect for all.

The Birmingham Civil Rights Institute owes its origins and evolution to a number of collaborative projects between libraries, archives, and museums. In 1977, Birmingham Mayor David Vann suggested that a civil rights museum would be an appropriate project for the city, and the following year his recommendation was endorsed by the city council. Although Mayor Vann was defeated in his bid for re-election in 1979, Dr. Richard Arrington, Jr., Birmingham's first African American mayor, received authorization from the city council to establish a museum committee to conduct a feasibility study. Arrington appointed Vann and University of Alabama at Birmingham historian, Dr. Horace Huntley, to co-chair the committee, and in 1982, the city began acquiring property for a new civil rights museum. But over the next several years, voters turned down bond issues that would have provided funds for the museum and other city projects. Arrington persisted, however, appointing a task force to develop a program statement and plans for the new facility. One of the task force appointees was Birmingham city archivist Dr. Marvin Whiting, who was also the head of archives for the Birmingham Public Library. When the city council finally established the Birmingham Civil Rights Institute (BCRI) in 1990, Whiting was appointed as a member of the incorporating board of directors. In his capacity as a board member, Whiting directed the efforts to collect items for the museum component of the Institute and also offered suggestions for the operational aspects of the facility. After BCRI opened its doors to the public in November 1992, Whiting continued to guide the design of the archives area as well as its content. In March 1993, he was involved in hiring an assistant archivist, who was also a librarian from the Birmingham Public Library. The assistant archivist helped Whiting to field inquiries from possible donors and to sort through the many boxes of items that had already been acquired.

My tenure at BCRI began in July 1995. Our present head of archives, Wayne Coleman, joined us that December. From the time of his arrival, Coleman recognized the importance of having BCRI remain connected to the Birmingham Public Library. Not only did this allow us to tap into Dr. Whiting's knowledge of Birmingham's history, it also enabled us to develop collection policies and procedures for using our archives in accordance with library policies that had been in place for many years. The Birmingham Public Library furthermore hosted the first BCRI Web site. In essence, we functioned at the time as a branch of the library system. Today, BCRI is a different facility, but all the wiser because of our early collaboration with the Birmingham Public Library.

Since our founding, BCRI has engaged in many other collaborations and partnerships, especially though our education department, which facilitates outreach 
presentations on request from schools and other community organizations in the greater Birmingham-Metro area. The presentations are provided free of charge. The department also develops online exhibits and curriculum materials that are available through our Web site.

In our facility, the Richard Arrington Jr. Resource Gallery serves as an interactive extension of BCRI's education department, archives division, and permanent exhibitions; at the same time, it emphasizes the larger mission of the Institute's civil and human rights focus. The gallery contains a combination of open and enclosed spaces designed to give visitors access to study areas, video viewing rooms, and computer stations. A variety of computer applications are complemented by a custom-configured software package developed around audio and video interview tapes from the Institute's ongoing oral history project. It contains over one hundred interview segments and includes images of numerous documents, newspapers, photographs, films, and other materials.

Educational programs, an innovative $\mathrm{K}-12$ curriculum guide, online oral histories, and the onsite Arrington Resource Center help thousands of school children each year learn about the Civil Rights Movement. In fact, school children make up sixty percent of our visitors. In addition, BCRI helps teachers by sponsoring workshops where they can share instructional resources.

One of our important partnership projects, the Civil Rights segment of the Teachers' Domain Web site, ${ }^{1}$ is specifically aimed at high school teachers. It is a collaborative venture between the Media Library of WGBH Educational Foundation, the archives of Washington University at St. Louis, and BCRI. The goal, as stated in the original grant proposal, has been to "produce an easily accessible means for getting high quality media into the hands of educators and students in a form that is directly targeted to their teaching and learning needs, in effect 'unlocking the vaults' of civil rights-related resources within each of the partnering institutions." More than half a million dollars of support has come from the Institute of Museum and Library Services (IMLS) and the partner institutions.

Teachers' Domain was founded on the concept of a true "digital library." Schools today are increasingly connected to the Internet and possess other means of electronic teaching and learning, but they have problems finding content of high quality. Meanwhile, museums, libraries, and archives are bursting with rich content, but they have difficulty in either reaching the public or in maximizing the public's use of their content.

1. See http://www.teachersdomain.org. 
Teachers' Domain content is intended for use by grades nine through twelve. It contains lesson plans that are correlated to national standards as well as individual state standards. Resources on the Teachers' Domain site include oral history interview clips (some taken from BCRI's unique collection of more than 450 interviews); interview transcripts; and other documents, such as correspondence between social justice activists, records of civil rights organizations, flyers and posters from the Civil Rights Movement, and film and television news footage.

Yet another collaborative outreach project in which BCRI plays a leading role is the Birmingham Cultural Alliance Partnership (BCAP). BCAP is an after-school program that involves middle school students in hands-on activities at eight of the city's most outstanding cultural institutions. More than 1,000 students and their families have participated in the project, which was initially funded by IMLS in the year 2000 through a two-year National Leadership Grant totaling $\$ 216,000$. Partner institutions include Birmingham city schools, BCRI, the Alabama Jazz Hall of Fame, the Birmingham Botanical Gardens, the Birmingham Museum of Art, the Birmingham Public Library, the McWane Science Center, Sloss Furnaces National Historic Landmark, and the Southern Museum of Flight. The goal of the project has been to encourage people in underserved communities to become lifelong learners and supporters of cultural institutions, and its objectives are to reinforce classroom learning, enhance student achievement, and promote parental involvement. In 2002, with support from the Alabama State Department of Education, BCAP expanded the program to offer comprehensive after-school services at two middle and elementary schools.

BCAP has been called "A Model After-School Program.” In February 2001, it was featured on the IMLS Web site as a "national model for museum and library collaboration." In 2002, BCAP was included on IMLS panels at the annual meetings of the American Library Association and the Society of American Archivists. BCAP has been spotlighted at national meetings of the Association of African American Museums, Alabama Museums Association, American Association for State and Local History, Southeastern Museums Conference, and the American Association of Museums. In April 2006, BCAP was named one of fifty national semifinalists for the President's "Coming up Taller Award," presented jointly by the White House, IMLS, the National Endowment for the Arts, and the National Endowment for the Humanities.

In closing, let me offer some practical advice based on what we have learned from our various collaborative ventures and partnerships. It is important always to:

- research all potential projects thoroughly,

- make certain they are well planned, 
- use available technology to maximize access,

- create win-win collaboration,

- engage students early,

- involve their parents,

- involve members of your targeted audience when planning programs,

- use your influence to encourage the development of diverse boards and staffs that reflect your community,

- be prepared for the long haul — things do not change overnight, and

- think positively and expect to be successful.

And remember: our future can be a bright one, because what you perceive, you can achieve. 